\title{
PELATIHAN GURU-GURU KIMIA DALAM PEMBUATAN VIDEO AJAR UNTUK PEMBELAJARAN DARING
}

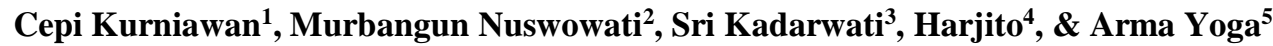 \\ 1,2,3,4,5 Fakultas Matematika dan Ilmu Pengetahuan Alam, Universitas Negeri Semarang \\ Email: kurniawan.cepi@mail.unnes.ac.id
}

\begin{abstract}
The period of the COVID-19 pandemic in Indonesia which began in March 2020 forced all teaching and learning processes to be shifted to an online learning system. Apart from the absence of a teacher culture in managing online learning, the implementation of this face-to-face teaching and learning process has forced teachers to be more creative in making learning media. In addition to the practical aspects, teachers must be ready and prepared to be able to play a role as the curriculum demands. The quality of online learning has roots that are not simple, starting from the lack of online learning resources, control of study time, internet access, and so on. Referring to the description of the situation analysis, the main problems of partners can be identified, namely science teachers, especially in the in-service Chemistry Teachers group. There is an increase in the skills of teachers in describing chemical molecular structures and also the ability to prepare teaching videos using PowerPoint. However, the device does not have support for rendering video if PowerPoint has lots of images and I or videos.
\end{abstract}

Keywords: online-learning; COVID-19; Chemistry Teachers; Teaching Video; PowerPoint.

\begin{abstract}
ABSTRAK: Masa pandemic COVID-19 di Indonesia yang dimulai pada bulan Maret 2020 memaksa semua proses belajar mengajar dialihkan pada sistem pembelajaran daring (online). Terlepas dari belum terbangunnya kultur guru dalam mengelola pembelajaran daring, pemberlakuan proses belajar mengajar tanpa tatap muka ini telah memaksa guru lebih kreatif dalam membuat media pembelajaran. Di samping aspek praktis, Guru-guru harus siap dan menyiapkan diri untuk mampu berperan sebagaimana tuntutan kurikulum. Kualitas pembelajaran daring mempunyai akar permasalahan yang tidak sederhana, mulai dari minimnya sumber belajar daring, kendali waktu belajar, akses internet, dan lainnya. Mengacu uraian pada analisis situasi dapat diidentifikasi permasalahan utama mitra yaitu guru sains utamanya pada kelompok Guru Kimia PPG Daljab 2020. Terdapat peningkatan keterampilan guru dalam menggambarkan struktur molekul kimia dan juga kemampuan menyiapkan video ajar menggunakan PowerPoint. Namun, devais yang dimiliki kurang support untuk rendering video jika PowerPoint memiliki banyak gambar dan atau video.
\end{abstract}

Kata Kunci: Pembelajaran daring; covid-19; Guru Kimia; video ajar; PowerPoint.

\section{PENDAHULUAN}

Pendidikan merupakan pusat bagi kemajuan sebuah bangsa, melalui pendidikan dapat diketahui kemana negara akan dibawa dalam mengikuti arus globalisasi maupun modernisasi. Pendidikan sebagai Grand kemajuan bangsa menjadi perhatian khusus oleh berbagai pihak terutama pemerintah (Depdiknas, 2020), Astuti, 2003)). Beberapa masalah mendasar yang sangat berpengaruh terhadap essensi lembaga pendidikan secara berkesinambungan terus diupayakan oleh pemerintah dengan berbagai cara, misalnya: pengembangan kurikulum, peningkatan kompetensi guru melalui pelatihan, pengadaan buku dan alat pelajaran, perbaikan sarana dan prasarana pendidikan, peningkatan mutu menejemen sekolah, dan sebagainya. Hakikat atau tujuan utama dari inovasi pendidikan adalah untuk membantu sekolah mencapai 


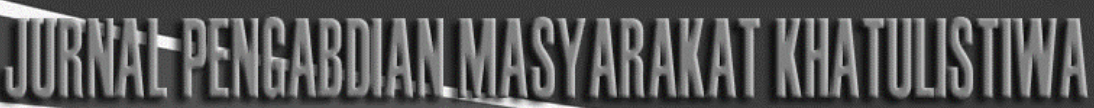

http:/jumalstkinippersada.ac:id/jumal/indexphp//JPMK E-ISSN 2550-5300

tujuannya secara efektif melalui penerapan sejumlah program atau praktek-praktek pendidikan yang lebih baik (Suprihatin, 2018)

Di era globalisasi saat ini, penyiapan sumber daya manusia (SDM) Indonesia berkualitas di masa depan merupakan tanggung jawab Pendidikan (Chaeruman (2017). Dalam lingkungan pendidikan di sekolah, keprofesionalime guru memegang kunci utama bagi peningkatan mutu tersebut, yang mencakup peningkatan pengetahuan, keterampilan, dan sikap peserta didik sebagai aset generasi penerus Indonesia masa depan. Tuntutan globalisasi dan modernisasi yang semakin maju dengan ditandai oleh rasionalisasi dalam berkarya yang sangat tinggi, haruslah diimbangi dengan kompetensi yang harus dimiliki oleh guru (Astuti, 2003)). Dengan kata lain peran guru sangat penting untuk dapat mengimbangi kondisi perkembangan peserta didik di sekolah. Selain memiliki pengetahuan yang tinggi dalam substansi bidang mata pelajaran, seorang guru dituntut pula untuk menunjukkan keterampilannya secara unggul dalam bidang pendidikan dan pembelajaran.

Pada awal maret 2020 virus corona atau biasa disebut dengan covid-19 sudah ada di Indonesia. Dalam perkembangannya virus corona tersebut telah menyebabkan kepanikan di tengah-tengah masyarakat. Hal itu menyebabkan ditutupnya beberapa sektor vital yang dianggap rentan untuk penyebaran virus corona, salah satunya adalah Lembaga pendidikan. Ada beberapa gejala yang dirasakan oleh orang yang terserang oleh virus ini, diantaranya adalah demam, batuk, pilek dan sesak napas. Corona virus Diseases 2019 (COVID-19) adalah penyakit jenis baru yang belum pernah diidentifikasi sebelumnya pada manusia. Apabila ada orang yang terkena corona virus maka, masa inkubasi rata-rata 5-6 hari dengan masa inkubasi terpanjang 14 hari (Ahsani, 2020).

Untuk menyikapi adanya virus corona ini Pada tanggal 24 maret 2020 kemendikbud mengeluarkan Surat Edaran Nomor 4 Tahun 2020 yang mengatur tentang bagaimana Pelaksanaan Pendidikan pada masa pandemik covid-19, pada surat edaran tersebut menjelaskan bahwa proses pembelajaran dialihkan yang awalnya dilakukan di sekolah menjadi pembelajaran dari rumah melalui pembelajaran online. Pembelajaran dari rumah dilakukan dengan tujuan untuk memutus mata rantai penyebaran covid-19.

Dengan semakin banyaknya pelatihan dan pembekalan guru dalam penyiapan proses belajar mengajar tentu penguasaan TIK bukan keniscayaan (Munir, 2009; Hanik, 2020). Namun, untuk menyiapkan media pembelajaran online, banyak guru yang merasa "kaget" dan bingung dengan media yang harus disiapkan. Selain itu, kimia merupakan ilmu yang tidak cukup dipelajari hanya dengan membaca materi atau penugasan. Pendampingan atau fasilitasi siswa merupakan keharusan. 


\section{METODE PELAKSANAAN}

Metode yang dilakukan dalam pelatihan pembelajaran daring ini adalah dengan cara pelatihan secara langsung. Tujuannya agar guru dapat memahami materi pelatihan dengan baik dan bisa mempraktikkannya secara langsung. Langkah-langkah yang dilakukan pada kegiatan pelatihan ini adalah:

1. Menerapkan protokol Kesehatan sebelum, Ketika dan sesudah melakukan pelatihan.

Dalam pelaksanaan pelatihan dilakukan penerapan protokol Kesehatan oleh semua peserta yang mengikuti pelatihan. Hal ini harus dilakukan mengingat pemerintah telah menerapkan sosial distancing. Pelaksanaan ini diberlakukan sebelum, Ketika dan sesudah para peserta memasuki ruangan. Penerapan protokol kesehetan merupakan salah satu syarat dilaksanakan pelatihan pembelajaran daring.

2. Memperkenalkan tentang pembelajaran daring

Pada kegiatan ini dilakukan pengenalan terhadap pembelajaran dalam jaringan (daring). Pembelajaran dalam jaringan (daring) merupakan pembelajaran yang dilakukan melalui jaringan internet. Media yang dipergunakan dalam pembelajaran daring ini bisa berupa facebook, whatshap, zoom meeting, google clasroom dan aplikasi aplikasi sejenis yang bisa dimanfaatkan dalam proses pembelajaran.
Dalam kegiatan ini guru juga diberikan kesempatan untuk bertanya terkait dengan pembelajaran daring, baik tentang kekurangan atau kelebihan dari masing-masing aplikasi yang biasa digunakan dalam pembelajaran dalam jaringan. Hal ini dilakukan agar setiap guru bisa memilih media apa yang paling sesuai untuk melakukan pembelajaran.

3. Menjelaskan tentang video ajar berbasis PowerPoint dan cara pembuatannya.

Sebagai pendahuluan dalam kegiatan ini, maka dilakukan konfirmasi terkait dengan media yang dimiliki guru untuk dijadikan media dalam proses pembelajaran daring apakah berupa Microsoft PowerPoint atau berupa catatan/modul.

Selanjutnya, narasumber mendemonstrasikan konversi Powerpoint menjadi video dan mengunggahnya di channel youtube. Metode penelitian menjelaskan rancangan kegiatan, ruang lingkup atau objek, bahan dan alat utama, tempat, teknik pengumpulan data, definisi operasional variabel penelitian, dan teknik analisis.

\section{HASIL DAN PEMBAHASAN}

Peserta yang terlibat dalam penelitian ini ada 26 Guru. Seluruh peserta sangat antusias dengan program pelatihan. Selama proses pelatihan terungkap juga bahwa sekolahsekolah mereka sudah terkoneksi dengan Microsoft, artinya untuk lisensi PowerPoint sudah dimiliki oleh pihak sekolah. Sehingga tidak khawatir terjadi pelanggaran hak cipta. 
http:/jumalstlkippersada.ac:id/jumal/index:php/JPMK

Gambar 1 menunjukkan proses diskusi setelah Narasumber 1 menyampaikan pemaparannya. Dari diskusi diperoleh gambaran bahwa seluruh guru sudah terbiasa menyiapkan materi berbantuan PowerPoint.

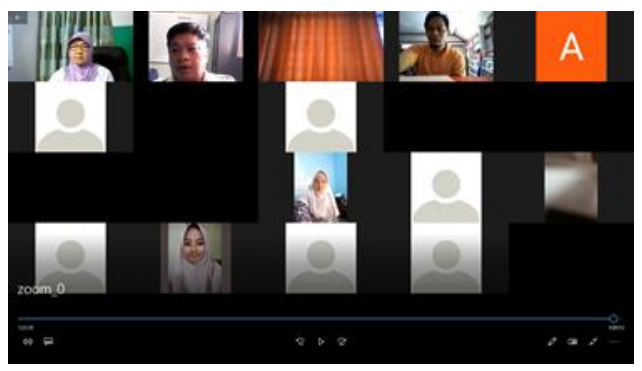

Gambar 1. Proses diskusi Narasumber dengan Para peserta pelatihan

Peserta belum memiliki keterampilan yang baik dalam menggambarkan molekul kimia (Gambar 2). Padahal penggamabran molekul merupakan salah satu cara untuk memvisualkan "kimia" yang abstak. Selanjutnya, narasumber memperkenalkan metode cara penggambaran molekul dengan menggunakan software Avogadro (Freeware) seperti ditunjukkan pada Gambar 3. Keterampil semacam ini perlu terus dilatihkan kepada guru agar kecakapan hidupnya juga menular kepada siswanya (Anggaraini, 2018).

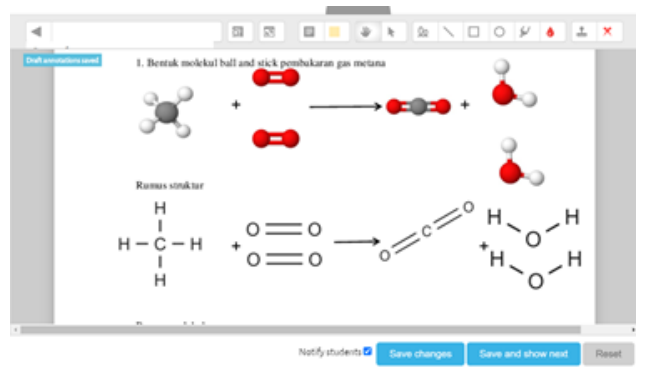

Gambar 2. Tugas pra pelatihan untuk mengetahui kemampuan guru dalam menggambar struktur molekul

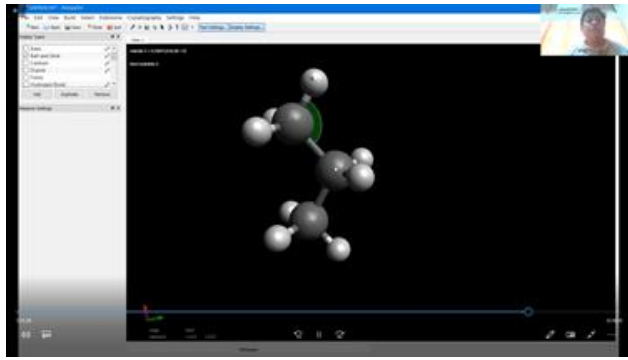

Gambar 3 menunjukkan proses naras umber menyampaikan pemaparan materi menggambar molekul untuk ditampilkan dalam video pembelajaran.

Pada akhir pelatihan, guru diminta membuat video dengan menggunakan panduan yang diberikan melalui pelatihan. Namun, tidak semua bisa membuat video yang ditugaskan. Salah satu permasalahannya adalah untuk mengkonversi PowerPoint Laptop/ computer yang dimiliki tidak support. Sehingga mereka lebih memilih menggunakan Zoom untuk membuat video pembelajaran (Gambar 4).
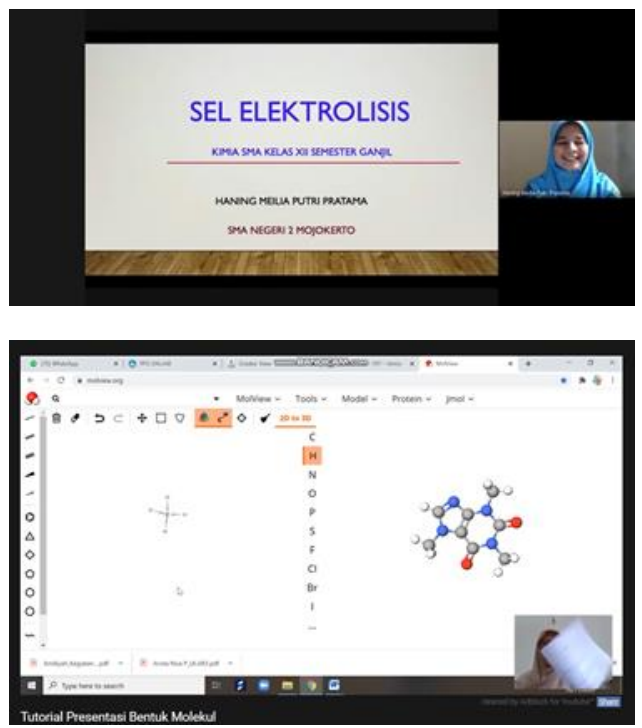

Gambar 4. Contoh tugas peserta yang diunggah di youtube

Berdasarkan pengalaman di lapangan, para guru juga dihadapkan pada kondisi bahwa siswa lebih menyukai interaksi langsung. 
Selain aspek praktis, interaksi antara guru dengan siswa dapat berlangsung lebih efektif. Namun demikian, guru dan siswa perlu mempertimbangkan kondisi dimana jaringan dan koneksi internet tidak selalu stabil disetiap daerah. Oleh karenanya, pengembangan sumber belajar mandiri dalam bentuk video ajar tetap dibutuhkan (Tim Kemenristekdikti, 2017))

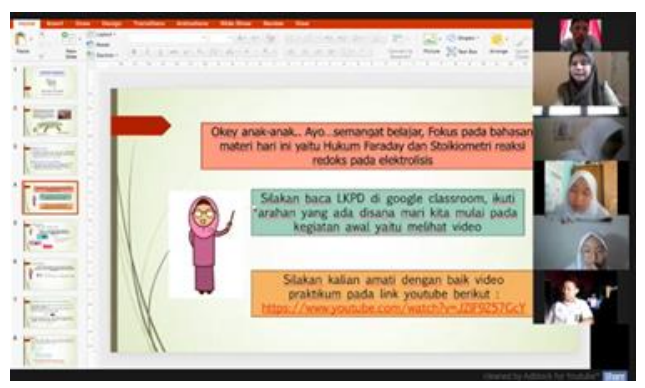

\section{Gambar 5. Screeshot Guru yang} menggunakan synchronous meeting.

\section{SIMPULAN}

Pelatihan pembuatan video kepada guruguru kimia pada kelompok guru kimia yang sedang mengikuti PPG Daljab 2020 berhasil diselenggarakan. Kegiatan ini mendapat respon positif dari peserta dan peserta mendapatkan keterampilan tambahan untuk menyiapkan video ajar.

\section{DAFTAR RUJUKAN}

Ahsani, E. L. F. (2020). Strategi Orang Tua dalam Mengajar dan Mendidik Anak dalam Pembelajaran At The Home Masa Pandemi Covid-19. Al Athfal: Jurnal Kajian Perkembangan Anak dan Manajemen Pendidikan Usia Dini, 3(1), $37-46$.

Anggraini, D. A. (2018). Pembelajaran Life Skill dengan Metode Belajar Bersama Alam (BBA) di SD Alam Harapan Kita
Klaten. Fakultas Ilmu Pendidikan Universitas Negeri Semarang.

Anwar. (2015). Pendidikan Kecakapan Hidup (Life Skill Education). Alfabeta.

Astuti D, S. I. (2003). Pengembangan Kecakapan Hidup (Life Skill) melalui Penanaman Etos Kerja dan Membangun Kreativitas Anak. Cakrawala Pendidikan, Th. XXII, No. 1.

Chaeruman, U. A. (2017). Pedati Model Desain Sistem Pembelajaran Blended. RISTEKDIKTI.

Departemen Pendidikan Nasional. (2002). Pola Pendidikan Kecakapan Hidup. SIC.

Depdiknas. (2002). Konsep Pendidikan Berorientasi Kecakapan Hidup. Depdiknas.

Ditjen PLPS. (2004). Pedoman Penyelenggaraan Program Kecakapan Hidup (Life Skill) Pendidikan Non Formal. Ditjen PLPS.

Hanik, E. U. (2020). Self Directed Learning Berbasis Literasi Digital Pada Masa Pandemi Covid-19 Di Madrasah Ibtidaiyah. ELEMENTARY: Islamic Teacher Journal, 8(1), 183-208.

Munir. (2009). Pembelajaran Jarak Jauh Berbasis Teknologi Informasi dan Komunikasi. CV. Alfabeta.

Pemerintah Republik Indonesia. (2003). Undang-Undang Republik Indonesia No 20 Tahun 2003 tentang Sistem Pendidikan Nasional.

Suprihatin, Y., \& Dewi, E. L. (2018). implementasi pendidikan lifeskill sejak dini dalam pembelajaran enterpreneurship (Studi pada SMP Cahaya Bangsa School Metro). Elementary: Jurnal Ilmiah Pendidikan Dasar, 85-96.

Tim Kemenristekdikti. (2017). Buku Panduan Pengisian Survei Pembelajaran dalam Jaringan. RISTEKDIKTI. 